\title{
A ten-year cross-national examination of the dance between intuition and rationality in entrepreneurial processes
}

\author{
${\text { C. } \text { Troise }^{1} \cdot \text { D. Matricano }}^{1}(1) \cdot$ E. Candelo ${ }^{2} \cdot$ L. Schjoedt $^{3}$ (1)
}

Accepted: 20 July 2021 / Published online: 14 December 2021

(c) The Author(s) 2021

\begin{abstract}
Entrepreneurs rely, to a degree, on intuition while they also rely on rationality. Both are associated with formation of expectations for new venture creation as well as perseverance of efforts in managing the new venture and its creation. Global Entrepreneurship Monitor data from three distinct countries over a ten-year period are used in logistic regression analysis to find, not unexpectedly, that intuition and rationality vary in impact across countries and over time. While the findings confirm past findings, they also provide intriguing new insights into the dance between intuition and rationality in entrepreneurial processes.
\end{abstract}

Keywords Entrepreneurship · Decision-making · Intuition · Rationality · Cross-national analysis $\cdot$ Longitudinal analysis

C. Troise

ciro.troise@unicampania.it

D. Matricano

diego.matricano@unicampania.it

E. Candelo

elena.candelo@unito.it

L. Schjoedt

leonschjoedt@ymail.com

1 Department of Economics, University of Campania "Luigi Vanvitelli”, Capua, Italy

2 Department of Management, Univeristy of Turin, Turin, Italy

3 Entrepreneurship Division Faculty, Babson College, Babson Park, MA, USA 


\section{Introduction}

Entrepreneurial processes are laden with uncertainty. It means that entrepreneurs have to rely on their intuition and rationality as they create and manage their new ventures. Intuition is instinctive thoughts that occur without conscious reasoning. Unlike intuition, rationality is a state of being agreeable to reason. In situations characterized by uncertainty, expectation refers to a belief about what is most likely to happen in the future whereas preservation refers to the continuation of efforts. As such, it is important to examine how intuition and rationality engages in a dance as entrepreneurs create and manage their new ventures (Allinson et al., 2000; Caputo \& Pellegrini, 2019; De Winnaar \& Scholtz, 2019; Deligianni et al., 2016; Mitchell et al., 2005; Shepherd et al., 2015).

With the preceding in mind, the goal of the present study is to examine how intuition and rationality impact entrepreneurs' expectations and perseverance. In the pursuit of this goal, two objectives are set for the study. The first objective is to test the impact that intuition-related factors (that is alertness to opportunities to create new ventures) and fear of failure; and rationality-related factors (that is, human capital in the shape of knowledge, skills, and abilities) entrepreneurs hold or are held by other entrepreneurs in their network, have on entrepreneurial processes (that reveal themselves by the act of new venture creation and by the management of established firms). Because little is known about regional differences in entrepreneurship (Jing et al., 2015), the second objective is to compare and contrast these relationships among the three distinct countries of China, Italy, and US on three continents over a ten-year period, specifically across 2006, 2012, and 2016. With this study, we seek to provide new insights into the dance between intuition and rationality in entrepreneurial processes.

To achieve these goals, we present our study as follows. Next, we consider the literature on factors of intuition and rationality. Rather than merely referring to a priori selected factors, milestones in the entrepreneurship literature will guide our choice of factors (Granovetter, 1985; Kirzner, 1973; MacMillan, 1986; Timmons, 1978). These literature considerations drive a set of eight hypotheses that will be tested. To do this, we describe the research methods employed in the study next. With the methods described, we present the results to determine whether the hypotheses are supported. Lastly, we summarize our findings, illustrate how these findings in combination provide new insights, and consider the study limitations to suggest potential opportunities for future research in a discussion.

\section{Theoretical background and hypotheses development}

Scholars agree on the idea that entrepreneurship is not a spot phenomenon (Johannisson, 2011; Leyden \& Link, 2015; Steyaert, 2007). It is a process originating with personal involvement and that is affected by many factors. Planned activities are combined with random occurrences, and predetermined actions may 
be replaced with rushed decisions. This means entrepreneurship is a process that is affected by planned activity and uncertainty.

In past research, scholars have investigated entrepreneurs' decision-making and actions (Krueger, 2003; Morales-Gualdrón \& Roig, 2005; Nord \& Fox, 1996). This research includes approaches like cognition (Krueger, 2003), microeconomic, psychological (Morales-Gualdrón \& Roig, 2005), institutional economics, and contextual analyses (Nord \& Fox, 1996). In recent years, scholars have begun to examine entrepreneurs' decision-making process (Gibcus et al., 2009; Mitchell et al., 2004, 2007; Sadler-Smith, 2004, 2016; Shepherd, 2015), even at the neuroscientific level (Shaver et al., 2017). In this body of research, scholars pay particular attention to the role that intuition and rationality play in decision-making (Allinson et al., 2000; De Winnaar \& Scholtz, 2019; Deligianni et al., 2016; Mitchell et al., 2005; Shepherd et al., 2015). In light of this, it may be expected that an appreciation of the dance between intuition and rationality in entrepreneurship has been examined; however, it has received scant attention from researchers. The underlying assumption in this dance between intuition and rationality is that entrepreneurs are torn between (1) a non-rational, fast system of thought based on an automatic, associative, and selective processing of tacit knowledge and explicit information (Kahneman, 2011; Lieberman, 2000; Stanovich \& West, 2000) and (2) a rational, deliberate but slower thought process based upon an effortful and rule-based processing of explicit information (Hogarth \& Karelaia, 2005; Kahneman, 2011; Stanovich \& West, 2000). An examination of the vast number of factors that may affect the dance between intuition and rationality in entrepreneurial processes ship may be beyond the scope of any study; therefore in this study, the evolution of the entrepreneurship literature pertaining to intuition and rationality will drive our development of the hypotheses.

\section{Intuition-related factors and expectations}

Upon Schumpeter (1911) published his seminal work on bringing innovation onto markets through the creation of new firms, scholars began investigating how individual differences affect entrepreneurship. Sutton (1954) examined the desire for responsibility. Davids (1963) investigated the desire for independence and selfconfidence. McClelland (1961) studied the desire for accomplishment (that is, the need for achievement). It was Kirzner (1973) to provide an alternative to this work in entrepreneurship by introducing the concept of alertness. In his view, entrepreneurship rests upon the "pure entrepreneur whose entire role arises out of his alertness to hitherto unnoticed opportunities" (p. 39). At its core, alertness is a subjective perception that a person has about opportunities for new venture creation. As this implies, it is not all people who perceive entrepreneurial opportunities. Such opportunity recognition is crucial in entrepreneurship (Zhao et al., 2020). This, in turn, affects people's interest and involvement in entrepreneurship (i.e. the launch of new ventures). It may be assumed from the work of Kirzner (Ardichvili et al., 2003; Baron \& Ensley, 2006; Blume \& Covin, 2011) that alertness to entrepreneurial opportunities is a form of entrepreneurial intuition. This entrepreneurial intuition, or alertness to entrepreneurial opportunities, may create a positive perceptual bias that 
results people form expectations about new venture creation (Dimov, 2007). Thus, we hypothesize:

H1: The more entrepreneurial opportunities entrepreneurs perceive, the higher the expectations are for launching new ventures.

Recognition of opportunities is not the only factor in launching a new venture. In fact, entrepreneurs evaluate if they can manage the activities necessary to launch the new venture; they consider entrepreneurial risk (Robinson \& Marino, 2015). Since the early considerations of the entrepreneur, entrepreneurial risk has been a factor in entrepreneurship (Cantillion, 1755; Mill, 1848). Considerations of entrepreneurs as risk bearers continue into modern entrepreneurship research (Churchill, 1997; Timmons, 1978). It should be elucidated that entrepreneurs are risk bearers, not necessarily risk takers. Scholars point out that entrepreneurs are moderate risk takers (Churchill, 1997; Timmons, 1978). As a risk bearer, entrepreneurs assume and manage the risk with which they perceive they can cope meaning that fear of failure is a critical factor in entrepreneurship (Cacciotti et al., 2016, 2020; Kollmann et al., 2017). Consequently, fear of failure may generate a perceptual bias, a negative perceptual bias that reduces the expectations for launching a new venture. Scholars (Arenius \& Minniti, 2005; Langowitz \& Minniti, 2007; Minniti \& Nardone, 2007; Wagner, 2007) have shown that fear of failure, an intuition, has a negative impact that lowers entrepreneurs' expectations. Therefore, we hypothesize:

H2: The higher level of entrepreneurs' perceived fear of failure, the lower the expectations for launching new ventures.

\section{Rationality-related factors and expectations}

An alternative to intuition per alertness (Kirzner, 1973) and fear of failure (Cacciotti et al., 2016, 2020; Kollmann et al., 2017) is rationality, which has been shown to be relevant in entrepreneurial processes. Based on the management literature (Conner \& Prahalad, 1996; Grant, 1996; Spender, 1996; Spender \& Grant, 1996), scholars have illustrated the relevance of knowledge-based rationality in entrepreneurship (Birley \& Westhead, 1993, 1994; Low \& MacMillan, 1988; MacMillan, 1986; McGrath \& MacMillan, 2000; Starr \& Bygrave, 1991; Ucbasaran et al., 2003a, 2003b; Westhead \& Wright, 1998a, 1998b; Wiklund \& Shepherd, 2008). In this perspective, entrepreneurship is not based on intuition in the form of alertness or fear of failure; instead, it is based on knowledge-driven rationality. Consequently, when entrepreneurs employ their human capital, that is their knowledge, skills, and abilities, they may form expectations to launch new ventures (Chitsaz et al., 2019; Davidsson \& Honig, 2003; Marvel et al., 2016; Matricano, 2016; Unger et al., 2011). Hence, we hypothesize:

H3: The more human capital, that is knowledge, skills, and abilities, entrepreneurs hold, the higher the expectations for launching new ventures.

Rationality in entrepreneurship has also been examined in the context of network theory (Aldrich \& Zimmer, 1986; Birley, 1985; Greve, 1995; Greve \& Salaff, 2003; Hoang \& Antoncic, 2003; Johannisson, 1986, 1988; Reynolds, 1991; Slotte-Kock \& Coviello, 2010; Starr \& MacMillan, 1990). A person's network offers potential 
access to the human capital of others in the network; as such, the network constitutes a potential resource of human capital for an entrepreneur. This means that if an entrepreneur can access others' human capital, it may be seen as enhancing the entrepreneur's human capital (Aldrich \& Zimmer, 1986). The opportunity to employ the human capital of others in the entrepreneur's network, such as others' previous entrepreneurial experiences, enhances the entrepreneur's expectations for new venture creation (Anderson et al., 2007; Chitsaz et al., 2019; De Carolis \& Saparito, 2006; Matricano, 2016). Thus, we hypothesize:

H4: The more human capital, that is knowledge, skills, and abilities, held by other entrepreneurs in an entrepreneur's network, the higher their expectations are for new venture launch.

\section{Intuition- and rationality-related factors and perseverance}

As previously pointed out entrepreneurship is not an activity that takes place at one point of time phenomenon (Johannisson, 2011; Leyden \& Link, 2015; Steyaert, 2007); it is a process that occurs over time. In entrepreneurship, perseverance, the doing of something despite its difficulty or any delay to achieve an outcome, is important. While the preceding four hypotheses pertained to expectations for launching new ventures, it takes time to create new ventures, and entrepreneurs are likely to encounter obstacles and delays as they create new ventures, it is important to also consider the impact of intuition and rationality on entrepreneurs' perseverance in managing the new ventures during the creation and afterwards. Experiences (driving to successful or unsuccessful results) are useful to entrepreneurs who can improve their ability to perceive what happens around them and can develop a better, in-depth knowledge of entrepreneurial matters (Baron \& Ensley, 2006; Ripsas, 1998; Shepherd et al., 2000). Intuition- and rationality-related factors developed because of direct involvement in entrepreneurship can exert a positive effect on the ongoing of firms that somehow recalls what MacMillan (1986) defines the "technology of entrepreneurship" in reference to habitual entrepreneurs. In particular, as argued by McGrath and MacMillan (2000), entrepreneurs are characterized by the passionate search for new business opportunities; by the enormous discipline in pursuing them; from the decision to pursue only the best; from the ability to adapt and, finally, from the use of personal energy in one's field of activity. The five characteristics listed-above underline the greater involvement that entrepreneurs show in activities aiming to identifying and pursuing business opportunities. These activities still depend on intuition and rationality (Westhead et al., 2005) and it is not possible to hypothesize if they depend more on intuition or rationality since they are the result of random occurrences that necessarily affect entrepreneurship (Ramoglou, 2021; Woo et al., 1994).

Accordingly, we present the following four hypotheses:

H5: The more new entrepreneurial opportunities entrepreneurs perceive, the longer time they will manage their ventures.

H6: The higher level of fear of failure of entrepreneurs perceive, the shorter time they will manage their ventures. 
H7: The more human capital entrepreneurs hold, the longer time they will manage their ventures.

H8: The more human capital held by other entrepreneurs in an entrepreneur's network, the longer time they will manage their ventures.

At this stage, the whole theoretical framework (including intuition- and rationality-related factors in reference to both start up and growth expectations) can be depicted in Fig. 1. The labels used to refer to each variable are shown in parenthesis.

In Fig. 1 is provided a graphical overview of the relationships hypothesized.

In the parenthesis are shown the labels for the variables and the associated hypotheses.

\section{Research method}

\section{Sample and data collection}

Data from the Global Entrepreneurship Monitor (GEM; gemconsortium.org) were used to test the hypotheses. GEM is a consortium of universities from around the world with the purpose of collecting data for the study of entrepreneurs and entrepreneurship to facilitate making comparisons across borders and over time (Reynolds et al., 1994, 2001, 2005; Morales-Gualdrón \& Roig, 2005; Mühlböck et al., 2018). These data rely on well-known measures and so they guarantee reliability and replicability of empirical analyses. GEM reports have significant impacts on entrepreneurship research and offer a relevant solution to an issue that existed until the late 1990s, namely the lack of comparable international data on entrepreneurship and venture creation (Bosma, 2013; Reynolds et al., 1994, 2005). As Bosma observes (2013, p. 143) "since 1999 GEM reports have been a key source of comparable data across a large variety of countries on attitudes toward entrepreneurship, start-up and established business activities, and aspirations of entrepreneurs for their businesses." This makes GEM data useful in comparative research and for this reason have been used in a multitude of studies (Aparicio et al., 2016; Arenius \& Kovalainen, 2006; Maula et al., 2005; Morales-Gualdrón \& Roig, 2005; Mühlböck et al., 2018; Ramos-Rodriguez et al., 2010).

To test our hypotheses, we employed GEM data for China, Italy and US from 2006, 2012 and 2016. Our choice to conduct a cross-cultural study was based

\begin{tabular}{|lcc|}
\hline \multicolumn{1}{|c|}{ Independent variables } & Dependent variables \\
\hline $\begin{array}{l}\text { Intuition: } \\
\text { - Perception/exploitation of entrepreneurial opportunities (OPP; H1; H5) }\end{array}$ & $\rightarrow$ \\
- Fear of failure/risk (FF; H2; H6) & Launching new ventures (LNV) \\
& & Managing ventures (MV) \\
Rationality: & $\rightarrow$ & \\
- Personal human capital (HC; H3; H7) & \\
- Others' human capital in the network (OHC; H4; H8) & \\
\hline
\end{tabular}

Fig. 1 Theoretical framework 
on two aspects: (1) little is known about regional differences in entrepreneurship (Jing et al., 2015) and (2) entrepreneurship research indicates that culture and country characteristics have important effects on people and on people's attitudes and behaviors (Chua et al., 2009; Dileo \& García Pereiro, 2019; Zheng et al., 2014). The inclusion of the US was based upon the rationale that a vast amount of published entrepreneurship research is conducted using samples from the US which provides opportunity for comparisons with a substantial amount of research in the extant literature. The choice of including China was based upon China is a fast growing economy with a high rate of new venture creation (He et al., 2019); plus it is profoundly different from the US. Lastly, we wanted to include an EU country that is not close in terms of culture to the US, such as the UK, while also having a lower entrepreneurial activity rate according to GEM than both the US and China. Based on these considerations, we chose Italy.

The choice of focusing on China, Italy and USA, allows us to explore intuition/ rationality in three different countries. New venture creation has fuelled a significant portion of the growth of these countries-as highlighted by several international reports (see among others annual GEM reports) - and there, in the last few decades, the entrepreneurial sector has grown rapidly as well as new regulations to foster entrepreneurship were introduced (Ahlstrom \& Ding, 2014; Dileo \& García Pereiro, 2019; He et al., 2019; Jing et al., 2015; Matricano, 2020; Troise \& Tani, 2021). As suggested by Jing et al. (2015), despite the internationalization background of entrepreneurship, little is known about the similarities and differences of entrepreneurial processes and their antecedents in different regions. Both intuition- and rationality-related factors may have different effects on entrepreneurial processes in different countries, however, currently little research has examined intuition and rationality from a cross-cultural perspective, although these parameters and the entrepreneurial processes may vary across cultures.

Our choice of the years 2006 and 2012 is based on a study provided by Mühlböck et al. (2018). These two years offer opportunity to make comparisons from before and after the global economic crisis. Furthermore, we also focus on the last database available at the time of data collection (Morales-Gualdrón \& Roig, 2005). Therefore, we added the data from 2016 because it is the last complete data set available at the time of this study and it represents the most recent possible situation of the current scenario. About this, it is appropriate to keep in mind that GEM full datasets are only made available to the public 3 years after data collection. The sample sizes for each of the countries and years are presented in Table 1.

Table 1 Samples

\begin{tabular}{llll}
\hline & 2006 & 2012 & 2016 \\
\hline China & 2399 & 3684 & 3974 \\
Italy & 1999 & 2000 & 2045 \\
US & 3012 & 5499 & 3000 \\
\hline
\end{tabular}




\section{Dependent, Independent, and Control Variables}

\section{Dependent variables}

The hypotheses require consideration of two dependent variables: expectations for launch of new ventures (LNV) in hypotheses 1-4 and perseverance in managing ventures (MV) in hypotheses 5-8. This choice is in line with previous studies (Arafat \& Saleem, 2017; Maula et al., 2005; Mühlböck et al., 2018). In the GEM data, LNV is a binary variable that was coded 1 , if respondents indicated they are planning to create a new venture in the next three years, and 0, if not (data source: GEM 2006, 2012, 2016 [futsup]). Also a binary variable is MV that was coded 1, if respondents indicate they manage and owns a business that has been in existence than no more 42 months, and 0, if otherwise (data source: GEM 2006, 2012, 2016 [babybuso]).

\section{Independent variables}

Intuition was assessed in two forms in accordance with the hypotheses: alertness to entrepreneurial opportunities (OPP) and fear of failure (FF). OPP reflects whether a participant perceive the existence of opportunities for new venture creation in the local area or not. It was coded as a binary variable with 1 , if the respondents perceive business opportunities, and 0, if not (data source: GEM 2006, 2012, 2016 [opport]). FF indicates whether a participant is afraid of failing with the creation of a new venture. This was coded as a binary variable with 1 , if respondents who indicate they fear failing when creating a new venture, and 0 , if not (data source: GEM 2006, 2012, 2016 [fearfail]).

Rationality was gauged in two ways by the entrepreneurs' human capital (HC) (that is, knowledge, skills, and abilities) and by other people's $\mathrm{HC}$ in the entrepreneurs' network (OHC). HC was a binary variable that was coded 1, if participants leveraged their human capital in the form of personal knowledge, skills, and abilities as part of the new venture creation, and 0, if not (data source: GEM 2006, 2012, 2016 [suskill]). OHC assessed if the participant's had potential to leverage the human capital of others in their network. In effect, $\mathrm{OHC}$ was a binary variable coded 1, if participants knew other entrepreneurs in their network, or 0, if not (data source: GEM 2006, 2012, 2016 [knowent]).

The data, including the coding schemes, were provided by GEM in the publically available data. The variables and their coding are in line with previous published research (Arafat \& Saleem, 2017; Maula et al., 2005; Morales-Gualdrón \& Roig, 2005; Mühlböck et al., 2018).

\section{Control variables}

Control variables were included in the study to rule out alternative explanations (Becker, 2005; Schjoedt \& Bird, 2014). This is a common practice in 
entrepreneurship research (as well as in other areas of research) according to Schjoedt and Sangboon (2015a, 2015b). Consistent with prior studies (Arafat \& Saleem, 2017; Morales-Gualdrón \& Roig, 2005; Mühlböck et al., 2018), we included three control variables: gender, age, and education. Gender, which has been shown to have an impact on entrepreneurship (Guelich et al., 2021), was coded as 0 for males and 1 for females (data source: GEM 2006, 2012 and 2016 [gender]). Age is a proxy for experience and has been shown to be associated with entrepreneurship (Gartner et al., 2004) and was expressed in years (data source: GEM 2006, 2012 and 2016 [age]). Education is expression of the level of formal education and is used in many studies as a proxy for human capital (Unger et al., 2011) as the purpose of education is to transfer explicit general knowledge to people. To control for the effects of explicit general knowledge, education was included as a control variable. It was coded 1 , if the participant had a high level of educational achievement (that is, post-secondary or higher level of education), and 0 , for a lower level of educational achievements as in previous research (Mühlböck et al., 2018) (data source: adapted from GEM 2006 and GEM 2012, 2016 [uneduc]). This approach of classifying education into high and low harmonizes the data across the years.

\section{Statistical analysis}

Logistic regression analysis was employed to analyse the data in testing the hypothesized relationships (define the explanatory power of our four independent variables) due to the use of binary dependent variables (Agresti, 2010; Hair et al., 2019; Long $\&$ Freese, 2006). Because of the two different dependent variables, we performed two sets of analyses, meaning two separate regression models for each of the years 2006, 2012 and 2016 for each of the three countries. It offers opportunity to compare the results across countries and years (Arafat \& Saleem, 2017; Greene, 2002).

The choice to use logistic regressions is in line with many other studies in the field of entrepreneurship (see among others Maula et al., 2005; Morales-Gualdrón \& Roig, 2005; Arafat \& Saleem, 2017; Mühlböck et al., 2018) and it allows us to identify the variables that explain the differences between groups (moreover these models do not consider data distribution). These models represent the most appropriate techniques for assessing the proposed hypotheses as they allow us "to predict and explain a dependent categorical binary variable via a group of independent covariables, amongst which not only qualitative (categorical) but also quantitative variables can be included" (Morales-Gualdrón \& Roig, 2005, p. 488).

Consistent with previous research (Arafat \& Saleem, 2017; Maula et al., 2005; Morales-Gualdrón \& Roig, 2005; Ramos-Rodriguez et al., 2010), we test the robustness of the models. First, we assessed multicollinearity, that is the correlation amongst independent variables. Second, using both the variance inflation factors (VIFs) and the correlation matrices for each year and country, we assess whether multicollinearity is a concern in the present study. Specifically, if the VIF is below the conventional thresholds [ 6 for the mean VIFs and 10 for the maximum VIFs (Kutner et al., 2005; Lin, 2008; McDonald \& Moffitt, 1980)] and the correlation 
is lower in magnitude than the threshold of 0.7 (Ratner, 2009), we considered the models robust.

\section{Results}

\section{Descriptive statistics and robustness checks}

Descriptive statistics are reported for each year respectively in Tables 2, 3 and 4.

As we expected, there are differences in entrepreneurial activity among China, Italy, and the US. In 2006, the percentages of participants who plan to create a new venture in the next three years is highest in China with about $36 \%$ and lower in both Italy with about $12 \%$ and in the US with about $11 \%$. In China about $11 \%$ of the participants manage and own a business. This percentage is $1.1 \%$ in Italy and $29 \%$ for the US.

Table 2 presents the descriptive statistics for year 2006. As for the independent variables, the table shows that OPP among the participants were about $34 \%$ in China; about $22 \%$ in Italy; and about $19 \%$ in the US. FF among the participants was about in China $24 \%$; $23 \%$ in Italy and $12 \%$ in the US. HC among the participants were about $35 \%$ in China; $28 \%$ in Italy; and $35 \%$ in the US. OHC among the participants were in China about $47 \%$; about $22 \%$ in Italy; and about $21 \%$ in the US. The control variables shown in the table reveal that the samples consisted of about half men and women. The average age among the participants was in China about 37 years; in Italy 47 years; and in the US 51 years. In terms of education, among the participants in China about $27 \%$ had a post-secondary education. This was in Italy about $19 \%$ and in the US about $64 \%$.

The average VIF is 1.19 for China; 1.13 for Italy; and 1.19 for the US for the variance inflation factors in Table 2. All the correlations presented in Table 2 are lower than 0.7 .

Comparing responses from 2006 with those from 2012 reveals that the participants, who plan to create a new venture in the next three years is higher in 2012 than in 2006: in China, about 22\%; in Italy, about 11\%; and in the US, about $13 \%$. Further, the participants, who manage and own a business, were lower in 2006: In China with about $7.7 \%$; in Italy, about $2.1 \%$; and in the US, about $3.7 \%$.

Table 3 presents the descriptive statistics for year 2012. Among the participants OPP is about $27 \%$ in China; $17 \%$ in Italy; and about $35 \%$ in the US. FF among the participants is about 35\% in China; $56 \%$ in Italy; and 35\% in the US. HC among the participants is about $35 \%$ in China; $29 \%$ in Italy; and $54 \%$ in the US. OHC among the participants is almost $51 \%$ in China; about $20 \%$ in Italy; and about $26 \%$ in the US. In 2012, the samples include slightly more women than men (on average about $52 \%$ ). The average ages in the samples were about 38 years in China; 43 years in Italy; and 50 years on the US. The participants who had post-secondary achievements were, in China, about 26\%; in Italy, almost 17\%; and in the US, about $58 \%$.

The average VIF in Table 3 are, for China, 1.09; for Italy, 1.04; and for the US, 1.05; and the highest VIF is well below 10. All the correlations are less than 0.7 in magnitude. 


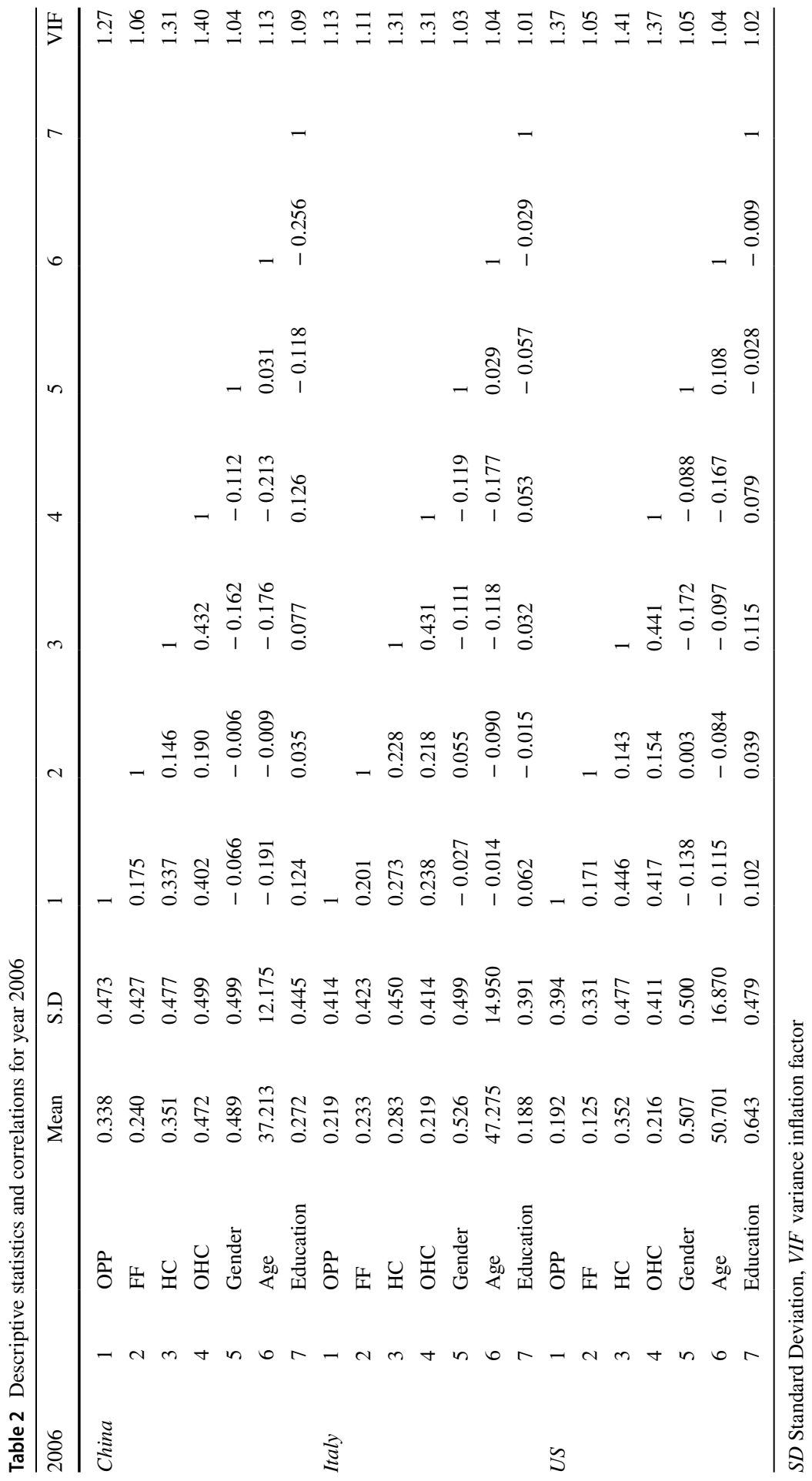




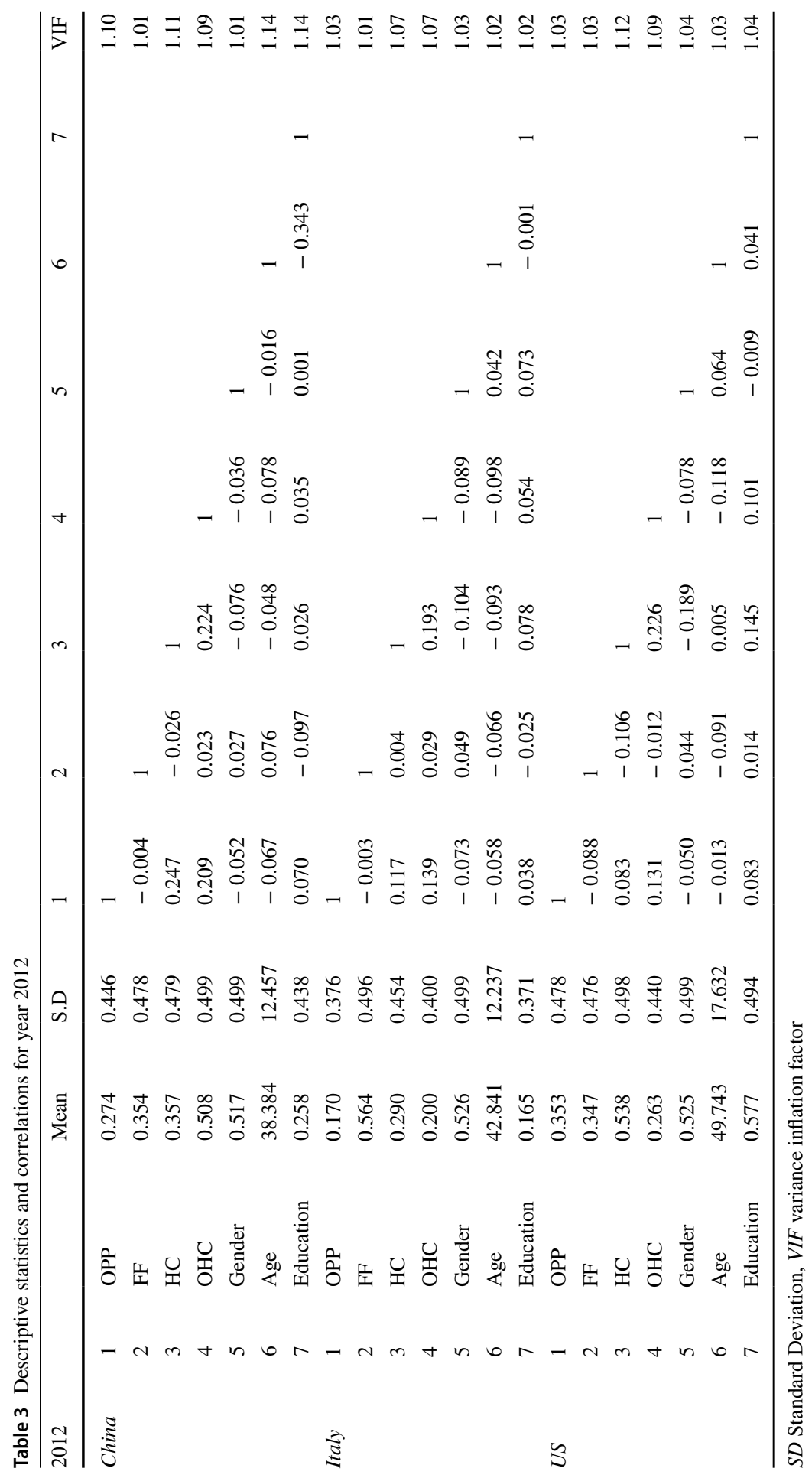




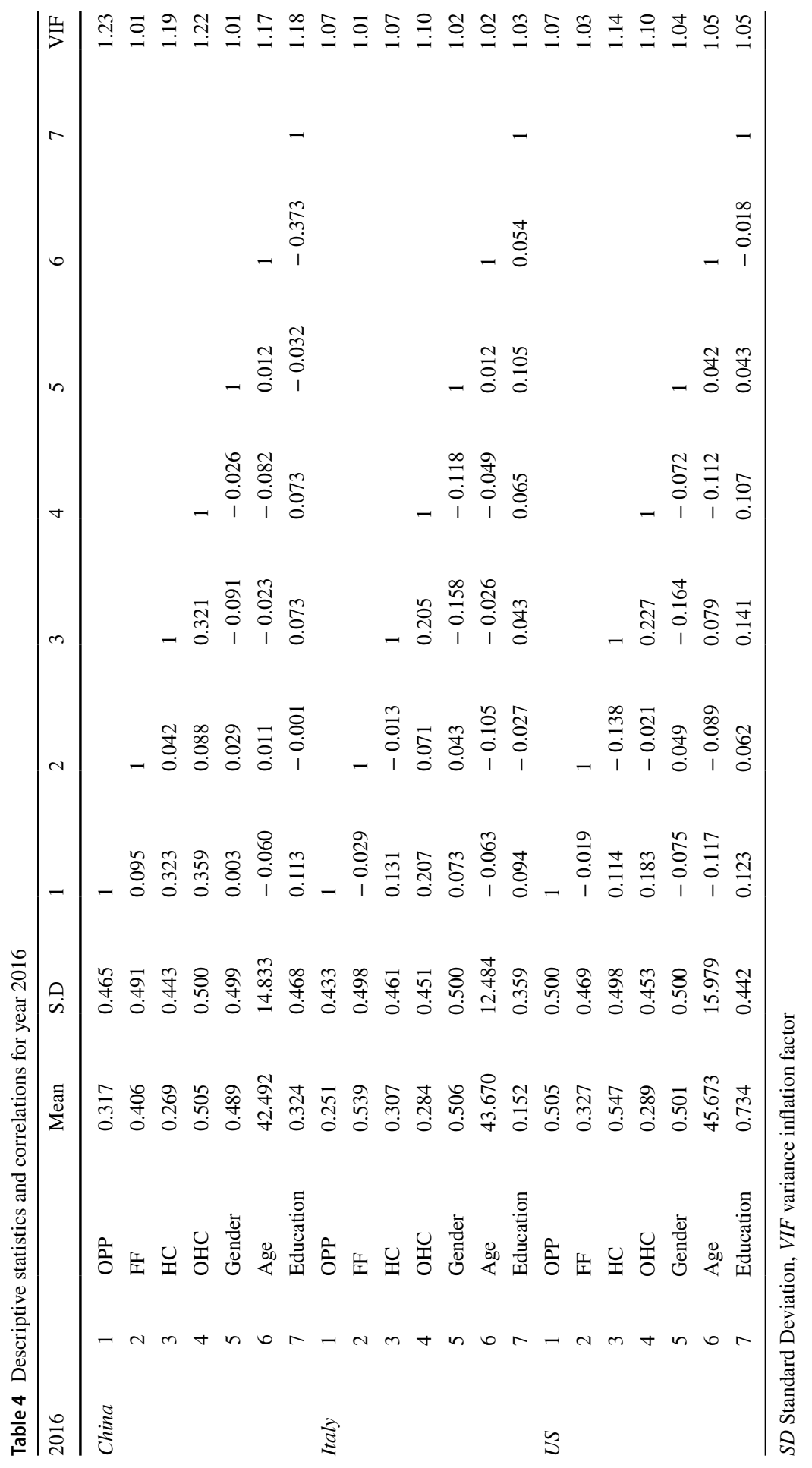


Comparing the number of participants who plan to create a new venture in the next three years in 2012 and 2016 reveal similar values: about $25 \%$ in China; about $11 \%$ in Italy; and about $15 \%$ in the US. The participants who own and manage a business are: about 5\% in China; about $1.8 \%$ in Italy; and about $3.5 \%$ in the US.

Table 4 shows the descriptive statistics for year 2016. OPP among the participants were about $32 \%$ in China; $25 \%$ in Italy; and over $50 \%$ in the US. FF in the participants was approximate $40 \%$ in China; about $54 \%$ in Italy; and about $33 \%$ in the US. HC among the participants was about $27 \%$ in China; $31 \%$ in Italy; and $55 \%$ in the US. OHC was over $50 \%$ in China; about $28 \%$ in Italy; and $29 \%$ in the US. The distribution of individuals in terms of gender is equally divided in the three countries. The age of participants was slightly over 42 years in China; a little more than 43 years in Italy; and over 45 years in the US. Participants with higher than secondary-level education was, in China, about 32\%; in Italy, a little over 15\%; and in the US, about $73 \%$.

The results presented in Table 4 mean that the average VIF is 1.14 for China; 1.05 for Italy; and 1.07 for the US. No correlation in Table 4 exceeds the magnitude of 0.7. As the results presented in Tables 2, 3, and 4 pertaining to robustness reveal that the models across country and across time are robust as all average VIFs are less than 6 , the highest VIF is less than 10, and the magnitude of any of the correlations is less than 0.7 .

\section{Logistic regression results}

In order to test the robustness of our findings, control variables and robust standard errors (in parentheses) are included in our models as shown in the tables.

Table 5 shows the logistic regression results related to 2006 with expectations (LNV) as dependent variable in model 1 and perseverance (MV) as dependent variable in model 2. As for Intuition, we found statistically significant evidence that OPP has full positive effects on our dependent variables for China and the US, while FF has only partial effects for China and Italy. For China, OPP has a positive impact on both LNV (model 1a, coefficient $=0.627$, significant at $1 \%$ ) and MV (model 2a, coefficient $=0.577$, significant at $1 \%$ ). Instead, FF has a positive impact only on LNV (model 1a, coefficient $=0.324$, significant at $1 \%$ ) and it has no statistically significant effects on MV. These results support H1, H2 and H5 but not H6. For Italy, for both OPP and FF has a positive significant effect on LNV only (model $1 \mathrm{~b}$, coefficients $=0.521$ and 0.653 , respectively, both significant at $5 \%$ ). No statistically significant effects on MV are found. The evidence supports $\mathrm{H} 1$ and $\mathrm{H} 2$ but not H5 and H6. For the US, OPP has a positive effect on both LNV (model 1c, coefficient $=1.262$, significant at $1 \%$ ) and MV (model $2 \mathrm{c}$, coefficient $=0.606$, significant at 5\%); whereas FF has no statistically significant effects on either dependent variable. This supports $\mathrm{H} 1$ and $\mathrm{H} 5$ but not $\mathrm{H} 2$ and $\mathrm{H} 6$.

These findings highlight that OPP has a positive effect in the three countries, but the strongest impact is for the US. On the other hand, FF has a positive impact only on LNV for China and Italy. This effect is strongest for Italy. 


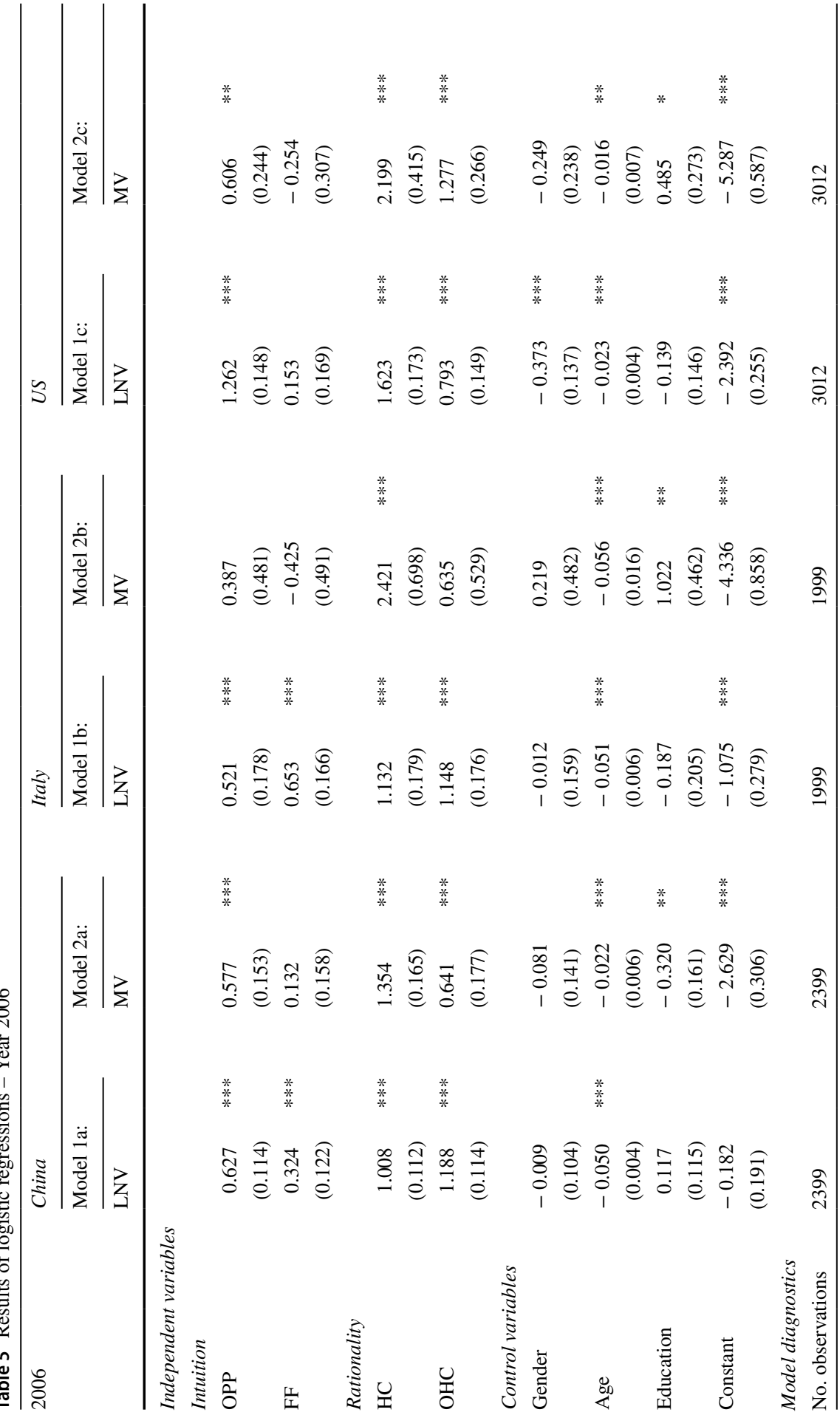




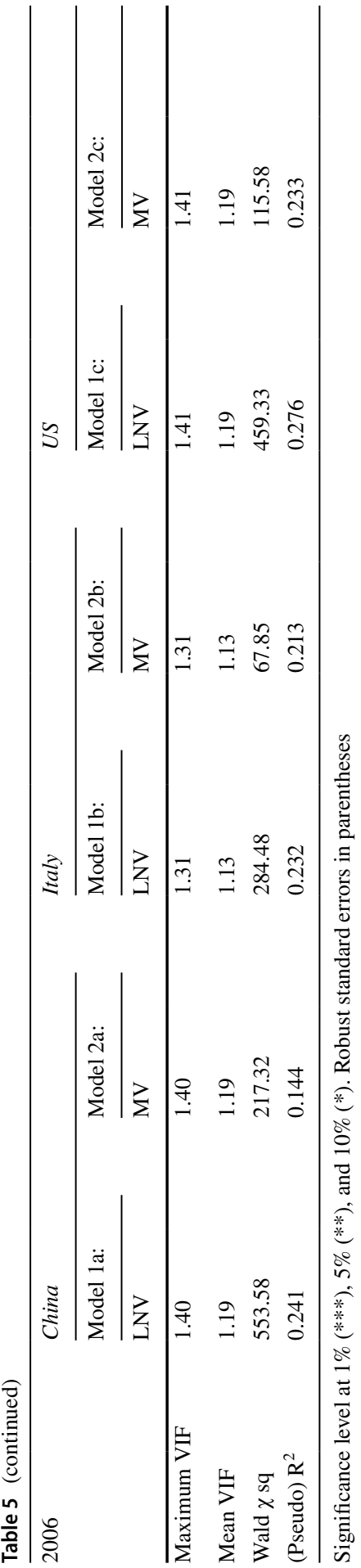


As for Rationality, a full positive significant effect on both our dependent variables is disclosed for China and the US, while this impact is partial for Italy. For China, HC has a positive effect on both LNV (model 1a, coefficient $=1.008$, significant at $1 \%$ ) and MV (model 2a, coefficient $=1.354$, significant at $1 \%$ ); and $\mathrm{OHC}$ has a positive impact on both LNV (model 1a, coefficient $=1.118$, significant at $1 \%$ ) and MV (model 2a, coefficient $=0.641$, significant at $1 \%$ ). These results render support for $\mathrm{H} 3, \mathrm{H} 4, \mathrm{H} 7$, and $\mathrm{H} 8$. For Italy, $\mathrm{HC}$ has a positive significant effect on both LNV (model 1b, coefficient $=1.132$, significant at 1\%) and MV (model 2b, coefficient $=2.421$, significant at $1 \%$ ); while $\mathrm{OHC}$ has a positive significant impact on LNV only (model $1 \mathrm{~b}$, coefficient $=1.148$, significant at $1 \%$ ). Contrary to expectations, OHC does not have a statistically significant effect on MV. This supports H3, $\mathrm{H} 4$ and $\mathrm{H} 7$, while $\mathrm{H} 8$ is not supported. For the US, HC has a positive significant effect on LNV (model 1c, coefficient $=1.623$, significant at $1 \%$ ) and on MV (model $2 \mathrm{c}$, coefficient $=2.199$, significant at $1 \%$ ). OHC has a significant positive effect on LNV (model 1c, coefficient $=0.793$, significant at $1 \%$ ) and on MV (model 2c, coefficient $=1.277$, significant at $1 \%$ ). These results support $\mathrm{H} 3, \mathrm{H} 4, \mathrm{H} 7$ and $\mathrm{H} 8$.

The results also indicate that $\mathrm{HC}$ has positive impacts on both MV and LNV in all the three countries while the impact is stronger on MV in Italy and the US. They also show that OHC has a weaker effect on LNV in the US and stronger effects in China and Italy. They also show that $\mathrm{OHC}$ has a stronger impact on $\mathrm{MV}$ in the US compared to Italy and China (while in these countries OHC values are similar, although it has no significant effect for Italy).

Table 6 shows the logistic regression results for 2012. As for Intuition, we found statistically significant evidence that OPP has full positive effects on our dependent variables for China and the US, while FF has only partial effects for the US. For China, OPP has a positive impact on both LNV (model 1d, coefficient $=0.577$, significant at $1 \%$ ) and MV (model 2d, coefficient $=0.328$, significant at 5\%). FF has no statistically significant effects on either LMV or MV. This supports H1 and H5 but not $\mathrm{H} 2$ and H6. For Italy, OPP has a positive significant impact on LNV only (model 1e, coefficient $=0.717$, significant at $1 \%$ ), but not on MV. FF has no significant impact on either LMV or MV. This supports H1 but do not support H2, H5, or H6. For the US, OPP has a positive impact on both LNV (model 1f, coefficient $=0.640$, significant at $1 \%)$ and MV (model $2 \mathrm{f}$, coefficient $=0.365$, significant at $5 \%$ ). FF has a negative statistically significant impact only on LNV (model 1f, coefficient $=-0.258$, significant at $1 \%$ ). The expectations suggested a positive effect, however this result is in line with previous studies (see among others Mitchell \& Shepherd, 2011). The scholars, in fact, argue that fear of failure does not only act as an inhibitory factor (thus confirming our hypothesis); but it can also act as a motivating factor, driving entrepreneurs to be proactive (this is related to the negative statistically significance derived from elaborations). This supports $\mathrm{H} 1$ and $\mathrm{H} 5$ but not $\mathrm{H} 2$ or H6. The results also show that OPP has a stronger impact on LNV for Italy while it has a stronger effect on MV for both the US and China. Further, they show that FF has a significant negative effect for the US only.

We find statistically significant evidence that Rationality has a positive impact on both our dependent variables in the three contexts explored. For China, HC has a positive effect on both LNV (model $1 \mathrm{~d}$, coefficient $=0.615$, significant at $1 \%$ ) and 


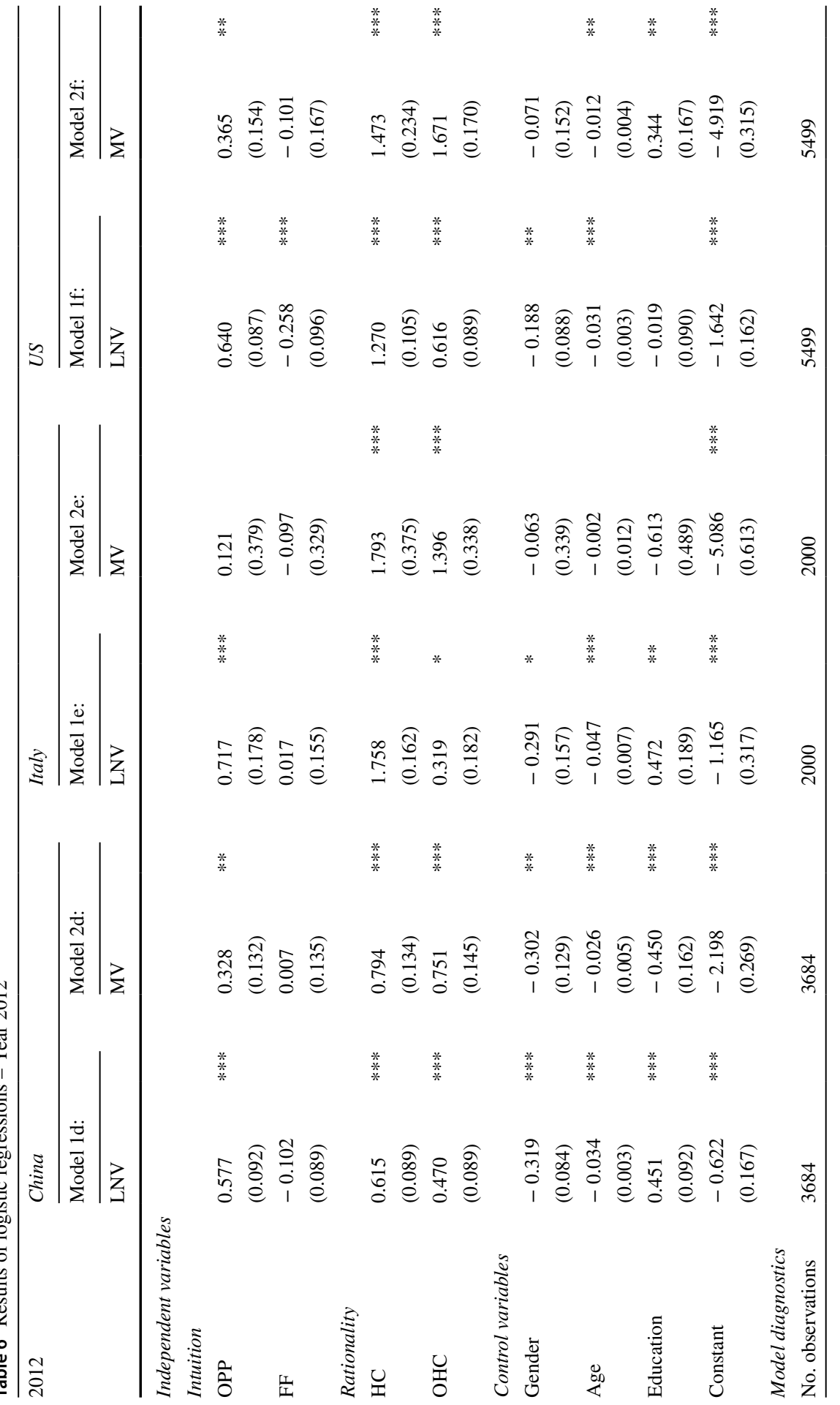




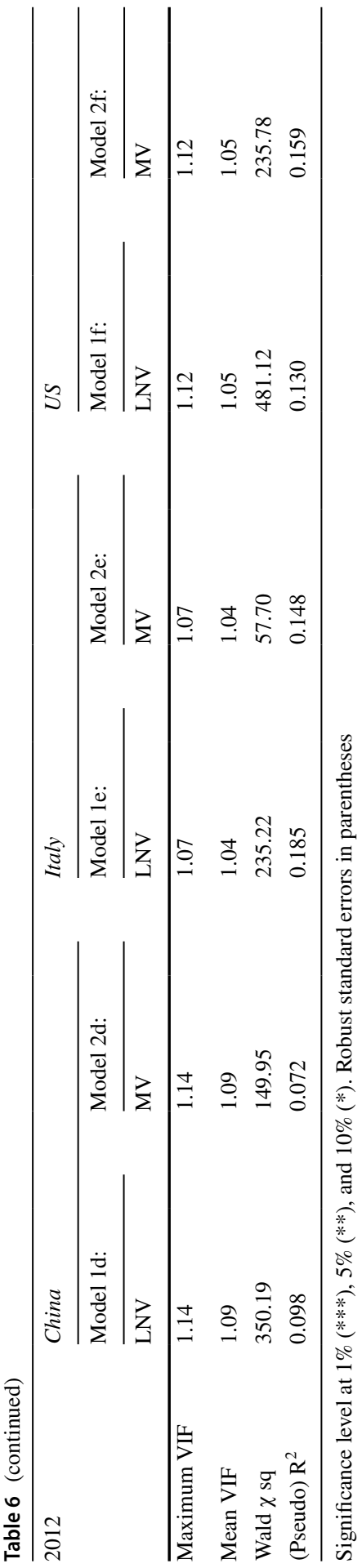


MV (model 2d, coefficient $=0.794$, significant at $1 \%$ ); and $\mathrm{OHC}$ also has a positive impact on both LNV (model $1 \mathrm{~d}$, coefficient $=0.470$, significant at $1 \%$ ) and MV (model $2 \mathrm{~d}$, coefficient $=0.751$, significant at $1 \%$ ). This supports $\mathrm{H} 3, \mathrm{H} 4, \mathrm{H} 7$, and H8. For Italy, HC has significant positive effect on both LNV (model 1e, coefficient $=1.758$, significant at $1 \%$ ) and MV (model 2e, coefficient $=1.793$, significant at $1 \%$ ). OHC also has a positive significant effect on both LNV (model 1e, coefficient $=0.319$, significant at $10 \%)$ and MV (model 2e, coefficient $=1.396$, significant at $1 \%$ ). These results provide support for $\mathrm{H} 3, \mathrm{H} 4, \mathrm{H} 7$, and $\mathrm{H} 8$. For the US, $\mathrm{HC}$ has a positive significant effect of $\mathrm{HC}$ on both LNV (model $2 \mathrm{f}$, coefficient $=1.270$, significant at $1 \%$ ) and MV (model $1 \mathrm{f}$, coefficient $=1.473$, significant at $1 \%$ ). OHC has a significant positive effect on both LNV (model $2 \mathrm{f}$, coefficient $=0.616$, significant at $1 \%$ ) and MV (model 1f, coefficient $=1.671$, significant at $1 \%$ ). These results lend support for $\mathrm{H} 3, \mathrm{H} 4, \mathrm{H} 7$, and $\mathrm{H} 8$. The results also show that $\mathrm{HC}$ has a stronger effect on both MV and on LNV for Italy. HC has significant effects on both LMV and MV in the US with higher values than in China. The results further show that $\mathrm{OHC}$ has a stronger impact on LNV and on MV in the US.

Table 7 shows the logistic regression results for 2016. As for Intuition, we found statistically significant evidence that OPP has full positive effects on LNV in the three countries, while found that FF has significant negative effects on MV in the three countries explored (while we expected a positive impact). For China, OPP has a positive impact on both LNV (model $1 \mathrm{~g}$, coefficient $=0.411$, significant at $1 \%$ ) and MV (model $2 \mathrm{~g}$, coefficient $=0.493$, significant at $1 \%$ ). And, FF has a significant negative effect on MV only (model $2 \mathrm{~g}$, coefficient $=-0.451$, significant at $1 \%$ ). These results provide support for $\mathrm{H} 1$ and $\mathrm{H} 5$ but not $\mathrm{H} 2$ and H6. For Italy, OPP has a positive impact on LNV only (model $1 \mathrm{~h}$, coefficient $=0.367$, significant at $5 \%$ ) but has no statistically significant effects on MV. FF has a significant negative impact on MV only (model $2 \mathrm{~g}$, coefficient $=-0.850$, significant at $5 \%$ ). This supports $\mathrm{H} 1$ but not $\mathrm{H} 2$, H5 or H6. For the US, OPP has a positive impact on LNV only (model $1 \mathrm{i}$, coefficient $=0.636$, significant at $1 \%$ ). FF has a negative statistically significant impact on MV only (model $2 \mathrm{i}$, coefficient $=-0.651$, significant at $5 \%$ ). This lends support for $\mathrm{H} 1$ but not $\mathrm{H} 2, \mathrm{H} 5$, or H6. The results also show that OPP has a strong and significant impact on MV only for China, while it has significant effects on LNV in all three countries with the strongest impact for the US. FF has a significant negative effect in all three countries, particularly for Italy.

We find statistically significant evidence that Rationality has a positive impact on both our dependent variables in the three contexts explored. For China, HC has a significant positive effect on both LNV (model $1 \mathrm{~g}$, coefficient $=0.527$, significant at $1 \%$ ) and MV (model $2 \mathrm{~g}$, coefficient $=1.309$, significant at $1 \%$ ). $\mathrm{OHC}$ has a positive significant impact on both LNV (model $1 \mathrm{~g}$, coefficient $=0.874$, significant at $1 \%$ ) and MV (model $2 \mathrm{~g}$, coefficient $=1.056$, significant at 1\%). This supports $\mathrm{H} 3$, $\mathrm{H} 4, \mathrm{H} 7$ and H8. For Italy, HC has a significant positive effect on both LNV (model $1 \mathrm{~h}$, coefficient $=1.721$, significant at $1 \%$ ) and $\mathrm{MV}$ (model $2 \mathrm{~h}$, coefficient $=1.327$, significant at 1\%). OHC has a positive significant effect on both LNV (model $1 \mathrm{~h}$, coefficient $=0.507$, significant at $1 \%)$ and MV (model $2 \mathrm{~h}$, coefficient $=1.572$, significant at 1\%). This supports $\mathrm{H} 3, \mathrm{H} 4, \mathrm{H} 7$ and $\mathrm{H} 8$. For the US, $\mathrm{HC}$ has a positive significant effects on both LNV (model 1i, coefficient $=1.055$, significant at $1 \%$ ) and 


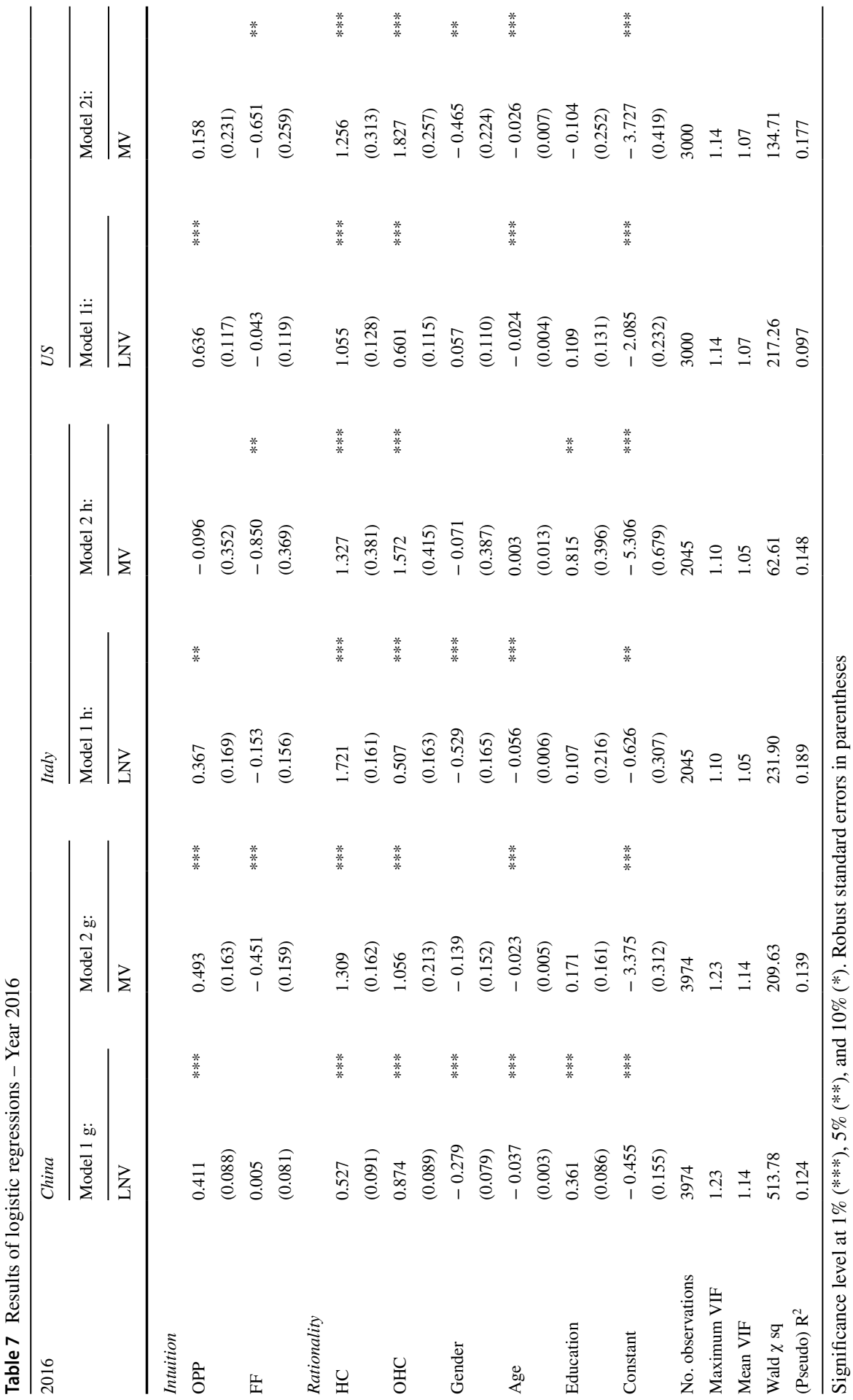


MV (model $2 \mathrm{i}$, coefficient $=1.256$, significant at $1 \%$ ). OHC has a significant positive effect on both LNV (model $2 \mathrm{i}$, coefficient $=0.601$, significant at $1 \%$ ) and MV (model 1i, coefficient $=1.827$, significant at $1 \%$ ). This supports $\mathrm{H} 3, \mathrm{H} 4, \mathrm{H} 7$ and $\mathrm{H} 8$. The results also show that $\mathrm{HC}$ has a stronger effect on LNV for Italy while it has a similar effect on MV in all three countries. They also show that OHC has a strongest impact on LNV for China and the strongest impact on MV for the US.

With the large number of hypotheses that are supported or not supported, and with hypotheses would have been supported if the relationship was in the opposite direction, it is necessary to gain an overview. Such an overview is provided in Table 8.

Table 8 reveals that $\mathrm{H} 1$ is supported for all three countries in each of the three years. H2 is supported in year 2006 for China and Italy but not the US; whereas it is not supported in any of the other two years. It is noteworthy to observe that if $\mathrm{H} 2$ was worded in a negative direction or direction-neutral, it would have been supported in the US in 2012. Both H3 and H4 are supported across all three countries in all years. H5 is supported across time in China; whereas it is not supported at any time in Italy. H5 is supported in the US in 2006 and 2012 but not in 2016. H6 is not supported in any country at any time. However, if worded in a negative direction, such a negatively worded H6 would be supported in all three countries in 2016. H7 is supported in all three countries across all three years. H8 is supported in China and the US but not in Italy in 2006 and is supported in all three countries in 2012 and 2016.

\section{Discussions and conclusions}

The purpose of the study was to investigate the dance between intuition and rationality in entrepreneurship; that is, the effects of intuition and rationality in entrepreneurial processes. Overall, we found that both intuition and rationality impacts entrepreneurial processes in three culturally distinct countries on three different continents, specifically China, Italy, and the US. In general, we found that intuition

Table 8 Overview of findings for China, Italy, and USA in years 2006, 2012, and 2016

\begin{tabular}{|c|c|c|c|c|c|c|c|c|c|}
\hline \multirow[b]{2}{*}{ HP } & \multicolumn{3}{|c|}{ China } & \multicolumn{3}{|l|}{ Italy } & \multicolumn{3}{|l|}{ US } \\
\hline & 2006 & 2012 & 2016 & 2006 & 2012 & 2016 & 2006 & 2012 & 2016 \\
\hline H1 & YES & YES & YES & YES & YES & YES & YES & YES & YES \\
\hline $\mathrm{H} 2$ & YES & NS & NS & YES & NS & NS & NS & RH & NS \\
\hline H3 & YES & YES & YES & YES & YES & YES & YES & YES & YES \\
\hline $\mathrm{H} 4$ & YES & YES & YES & YES & YES & YES & YES & YES & YES \\
\hline H5 & YES & YES & YES & NS & NS & NS & YES & YES & NS \\
\hline H6 & NS & NS & RH & NS & NS & RH & NS & NS & RH \\
\hline H7 & YES & YES & YES & YES & YES & YES & YES & YES & YES \\
\hline H8 & YES & YES & YES & NS & YES & YES & YES & YES & YES \\
\hline
\end{tabular}

Yes supported, $R H$ rival hypothesis supported, $N S$ not significant 
impacts entrepreneurs' expectations and rationality affects entrepreneurs' perseverance. It should be noted that these findings are not consistent for all countries and in all years. It is noteworthy that fear of failure, an intuition factor, unexpectedly had a positive effect on expectations and on perseverance in some years; specifically on expectations in 2012 for the US and on perseverance in year 2016 for all three countries. Also, fear of failure reduced expectations for both China and Italy in 2006. At no time did fear of failure reduce perseverance for any of the three countries. We found that rationality had a positive effect on expectations and perseverance for all three countries except for perseverance in Italy in 2006. Therefore, an overall conclusion may be carefully drawn that intuition and rationality are both partners in the dance of entrepreneurial processes.

Consistent with recent studies (Pattinson, 2019; Zivdar et al., 2017) and with our findings in mind, this study enriches the entrepreneurship literature by investigating entrepreneurship across countries and time as little is known about regional differences in entrepreneurship (Jing et al., 2015; Welter, 2011; Welter \& Gartner, 2016; Zahra, 2007; Zahra et al., 2014). The dance between intuition and rationality may, in part, depend on individual differences that are beyond the scope of this study, and as shown in this study depends, at least in part, on the external context and time. Our statistical elaborations disclose that the intensity of the dance between intuition and rationality in the entrepreneurship seems to vary depending on the country and time. Consequently, this study confirms that both intuition and rationality impacts entrepreneurship as the tested hypotheses were developed based on the extant literature. It also provides new insights by unexpectedly illustrating that the direction of some of the hypothesized relationships was in reverse; this is specifically pertaining to intuition as fear of failure may enhance entrepreneurs' expectations and perseverance. New insights are also gained from the consistency, or lack thereof, in the support for the hypotheses across the countries and times. It appears from considering the supported hypotheses that rationality is, what should we call it, a stable in entrepreneurship; while intuition is more temperamental, which may make the dance of entrepreneurship less straight forward and more interesting. This may explain why it seems difficult to provide a recipe for how to successfully launch and manage a new venture. We are going out on a limb when we say that both intuition and rationality are needed in entrepreneurship and it is the dance between the two that makes entrepreneurship unforeseeable and, therefore, interesting.

\section{Limitations and suggestions for future research}

As with all research, this study has its limitations. We will briefly address four limitations, which in turn suggest future research opportunities. First, the data employed in this study were secondary data retrieved from GEM. This limits our choice of statistical techniques (Arafat \& Saleem, 2017) and our choice for more dynamic analysis (Aparicio et al., 2016). While the GEM data offers opportunity to investigate more than one country at one time, the data is cross-sectional in nature preventing test of causality (Cook \& Campbell, 1979). Future research may provide new insights using additional or other countries and years (Aparicio et al., 2016; Caputo 
\& Pellegrini, 2019). This represents a promising avenue for future research and it opens up the possibility of developing further studies from here, in fact, we aim to extend this research by exploring other countries to compare differences or confirm our findings. This will allow us to verify if some similarities - beyond well-known differences - exist in reference to entrepreneurial decision-making processes.

Second, the use of GEM data reduces the opportunity to consider the details of the situations faced by the participants such a local culture or events. As research shows, cultural and other contextual factors influence participants' perceptions and responses (Drewniak \& Karaszewski, 2020; Schjoedt et al., 2018). Future research may benefit from employing richer data and a qualitative research design. Thus, even in this case, a future research opportunity emerges to shed further light in this field of research.

Third, control variables were included in the logistic regression analyses. While the three control variables included were considered relevant and have been used extensively in previous entrepreneurship research, they pose two problems (Schjoedt $\&$ Bird, 2014). The use of control variables means that the variables do not represent people found in reality; they represent fictitious people with fictitious scores (Meehl, 1970, 1971). The other problem is that only three control variables were included meaning that all alternative explanations were not controlled for in the data analyses. One way to overcome both issues is what Schjoedt and Bird (2014) refer to as a conservative approach in which no control variables are included. In Tables 5, 6, and 7, we provide a "kind of" approach to this conservative approach to control variables by conducting the logistic regression analyses and presenting the independent variables as the first step, before entering the control variables. As control variables explain independent variance in the dependent variables it may be fruitful for future research to follow our approach in the analyses and presentation of the results in addition to the inclusion of additional, yet conceptually relevant and justified control variables. Based on the above, a subsequent study could be developed taking these aspects into account.

Fourth, only two variables were used as factors of intuition and rationality each. While this approach yielded findings that were consistent with previous research as well as providing new insights, future research may advance our understanding of the dance between intuition and rationality based on employing different and additional factors of intuition and rationality (Dileo \& García Pereiro, 2019; Hui-Chen et al., 2014; Liñán \& Fayolle, 2015). Since other variables could be used for the same purpose - and therefore to frame intuition and rationality - we aim to extend this research by replicating the models and using new additional measures. In particular, the use of other parameters (e.g. not retrieved from GEM) would allow us to adopt further more accurate statistical techniques, such as structural equation model (SEM) (Guerrero et al., 2008; Miralles et al., 2016), and therefore to investigate the mutual interaction between the variables. These limitations will allow us to further discover the role of intuition and rationality in the entrepreneurial processes and the dance between them.

In conclusion, our study of intuition and rationality in entrepreneurship confirms existing knowledge. At the same time, it advances our understanding of the dance between intuition and rationality by providing new and interesting insights that 
could only be gained when examining this dance in multiple distinct countries such as China, Italy, and the US and at multiple times.

Funding Open access funding provided by Università degli Studi della Campania Luigi Vanvitelli within the CRUI-CARE Agreement.

Open Access This article is licensed under a Creative Commons Attribution 4.0 International License, which permits use, sharing, adaptation, distribution and reproduction in any medium or format, as long as you give appropriate credit to the original author(s) and the source, provide a link to the Creative Commons licence, and indicate if changes were made. The images or other third party material in this article are included in the article's Creative Commons licence, unless indicated otherwise in a credit line to the material. If material is not included in the article's Creative Commons licence and your intended use is not permitted by statutory regulation or exceeds the permitted use, you will need to obtain permission directly from the copyright holder. To view a copy of this licence, visit http://creativecommons.org/ licenses/by/4.0/.

\section{References}

Agresti, A. (2010). Analysis of ordinal categorical data. Wiley.

Ahlstrom, D., \& Ding, Z. (2014). Entrepreneurship in China: An overview. International Small Business Journal, 32(6), 610-618.

Aldrich, H. E., \& Zimmer, C. (1986). Entrepreneurship Through Social Networks. In H. E. Aldrich (Ed.), Popoluation Perspective on Organizations. Uppsala: Acta Universitatis Upsaliensis.

Allinson, C. W., Chell, E., \& Hayes, J. (2000). Intuition and entrepreneurial behaviour. European Journal of Work and Organizational Psychology, 9(1), 31-43.

Anderson, A., Park, J., \& Jack, S. (2007). Entrepreneurial social capital: Conceptualizing social capital in new high-tech firms. International Small Business Journal, 25(3), 245-272.

Aparicio, S., Urbano, D., \& Audretsch, D. (2016). Institutional factors, opportunity entrepreneurship and economic growth: Panel data evidence. Technological Forecasting and Social Change, 102, 45-61.

Arafat, M. Y., \& Saleem, I. (2017). Examining start-up Intention of Indians through cognitive approach: A study using GEM data. Journal of Global Entrepreneurship Research, 7(13), 1-11.

Ardichvili, A., Cardozo, R., \& Ray, S. (2003). A theory of entrepreneurial opportunity identification and development. Journal of Business Venturing, 18(1), 105-123.

Arenius, P., \& Kovalainen, A. (2006). Similarities and differences across the factors associated with women's self-employment preference in the nordic countries. International Small Business Journal, 24(1), 31-59.

Arenius, P., \& Minniti, M. (2005). Perceptual variables and nascent entrepreneurship. Small Business Economics, 24(3), 233-247.

Baron, R. A., \& Ensley, M. D. (2006). Opportunity recognition as the detection of meaningful patterns: Evidence from comparisons of novice and experienced entrepreneurs. Management Science, 52, 1331-1344.

Becker, T. E. (2005). Potential problems in the statistical control of variables in organizational research: A qualitative analysis with recommendations. Organizational Research Methods, 8, 274-289.

Birley, S., \& Westhead, P. (1993). A Comparison of New Business Established by "Novice" and "Habitual" Founders in Great Britain. International Small Business Journal, 12(4), 38-60.

Birley, S., \& Westhead, P. (1994). A taxonomy of business start-up reasons and their impact on firm growth and size. Journal of Business Venturing, 9(1), 7-31.

Birley, S. (1985). The role of networks in the entrepreneurial process. Journal of Business Venturing, 1(1), 107-117.

Blume, B. D., \& Covin, J. G. (2011). Attributions to intuition in the venture founding process: Do entrepreneurs actually use intuition or just say that they do? Journal of Business Venturing, 26(1), $137-151$. 
Bosma, N. (2013). The global entrepreneurship monitor (GEM) and its impact on entrepreneurship research. Foundations and Trends in Entrepreneurship, 9(2), 143-248.

Cacciotti, G., Hayton, J. C., Mitchell, J. R., \& Allen, D. G. (2020). Entrepreneurial fear of failure: Scale development and validation. Journal of Business Venturing, 35(5), 106041.

Cacciotti, G., Hayton, J. C., Mitchell, J. R., \& Giazitzoglu, A. (2016). A reconceptualization of fear of failure in entrepreneurship. Journal of Business Venturing, 31(3), 302-325.

Cantillion, R (1755). Essai sur la nature du commerce en general.

Caputo, A., \& Pellegrini, M. (2019). The Anatomy of Entrepreneurial Decisions Past, Present and Future Research Directions, Contributions to Management Science. Cham: Springer Nature.

Chitsaz, E., Tajpour, M., Hosseini, E., Khorram, H., \& Zorrieh, S. (2019). The effect of human and social capital on entrepreneurial activities: A case study of Iran and implications. Entrepreneurship and Sustainability Issues, 6(3), 1193-1203.

Chua, R. Y. J., Morris, M. W., \& Ingram, P. (2009). Guanxi vs networking: Distinctive configurations of affect- and cognition-based trust in the networks of Chinese vs American managers. Journal of International Business Studies, 40(3), 490-508.

Churchill, N. C. (1997). Breaking Down the Wall: Scaling the Ladder. In S. Birley \& D. Muzyka (Eds.), Mastering Enterprise. London: Pitman.

Conner, K. R., \& Prahalad, C. K. (1996). A resource-based theory of the firm: Knowledge versus opportunism. Organization Science, 7(5), 477-501.

Cook, T. D., \& Campbell, D. T. (1979). Quasi-experimentation: Design \& analysis issues for field settings. Houghton Mifflin.

Davids, L. E. (1963). Characteristics of small business founders in Texas and Georgia. University of Georgia, Athens.

Davidsson, P., \& Honig, B. (2003). The role of social and human capital among nascent entrepreneurs. Journal of Business Venturing, 18(3), 301-331.

De Carolis, D. M., \& Saparito, P. (2006). Social capital, cognition, and entrepreneurial opportunities: A theoretical framework. Entrepreneurship Theory and Practice, 30(1), 41-56.

De Winnaar, K., \& Scholtz, F. (2019). Entrepreneurial decision-making: New conceptual perspectives. Management Decision, 58(7), 1283-1300.

Deligianni, I., Dimitratos, P., Petrou, A., \& Aharoni, Y. (2016). Entrepreneurial orientation and international performance: The moderating effect of decision-making rationality. Journal of Small Business Management, 54(2), 462-480.

Dileo, I., \& García Pereiro, T. (2019). Assessing the impact of individual and context factors on the entrepreneurial process. A cross-country multilevel approach. International Entrepreneurship and Management Journal, 15, 1393-1441.

Dimov, D. (2007). From opportunity insight to opportunity intention: The importance of person-situation learning match. Entrepreneurship Theory and Practice, 31(4), 561-583.

Drewniak, R., \& Karaszewski, R. (2020). Diffusion of knowledge in strategic alliance: Empirical evidence. International Entrepreneurship and Management Journal, 16, 387-416.

Gartner, W. B., Shaver, K. G., Carter, N. M., \& Reynolds, P. D. (Eds.). (2004). Handbook of Entrepreneurial Dynamics: The process of business creation. Sage.

Gibcus, P., Vermeulen, P. A., \& De Jong, J. P. (2009). Strategic decision making in small firms: A taxonomy of small business owners. International Journal of Entrepreneurship and Small Business, 7(1), 74-91.

Granovetter, M. (1985). Economic action and social structure: The problem of embeddedness. American Journal of Sociology, 91(3), 481-510.

Grant, R. M. (1996). Toward a knowledge-based theory of the firm. Strategic Management Journal, 17(S2), 109-122.

Greene, W. H. (2002). Econometric analysis. Prentice Hall.

Greve, A. (1995). Networks and entrepreneurship. An analysis of social re-lations, occupational background, and the use of contacts during the establishment process. Scandinavian Journal of Management, 11(1), 1-24.

Greve, A., \& Salaff, J. W. (2003). Social networks and entrepreneurship. Entrepreneurship Theory and Practice, 28(1), 1-22.

Guelich, U., Bullough, A., Manolova, T., \& Schjoedt, L. (Eds.). (2021). Women's entrepreneurship and culture: Socio-cultural context. Edward Elgar Publishing. 
Guerrero, M., Rialp, J., \& Urbano, D. (2008). The impact of desirability and feasibility on entrepreneurial intentions: A structural equation model. International Entrepreneurship and Management Journal, $4,35-50$.

Hair, J. F. J., Black, W. C., Babin, B. J., \& Anderson, R. E. (2019). Multivariate data analysis. Hampshire: Cengage.

He, C., Lu, J., \& Qian, H. (2019). Entrepreneurship in China. Small Business Economics, 52, 563-572.

Hoang, H., \& Antoncic, B. (2003). Network-based research in entrepreneurship: A critical review. Journal of Business Venturing, 18(2), 165-187.

Hogarth, R. M., \& Karelaia, N. (2005). Simple models for multiattribute choice with many alternatives: When it does and does not pay to face trade-offs with binary attributes. Management Science, 51(12), 1860-1872.

Hui-Chen, C., Kuen-Hung, T., \& Chen-Yi, P. (2014). The entrepreneurial process: An integrated model. International Entrepreneurship Management Journal, 10, 727-745.

Jing, S., Qinghua, Z., \& Landström, H. (2015). Entrepreneurship research in three regions-the USA, Europe and China. International Entrepreneurship and Management Journal, 11, 861-890.

Johannisson, B. (1986). Network strategies: Management technology for entrepreneurship and change. International Small Business Journal, 5(1), 19-30.

Johannisson, B. (1988). Business formation: A network approach. Scandinavian Journal of Management, 4(3/4), 83-99.

Johannisson, B. (2011). Towards a practice theory of entrepreneuring. Small Business Economics, 36(2), $135-150$.

Kahneman, D. (2011). Thinking, fast and slow. Farrar, Strauss, Giroux.

Kirzner, I. M. (1973). Competition and entrepreneurship. University of Chicago Press.

Kollmann, T., Stöckmann, C., \& Kensbock, J. M. (2017). Fear of failure as a mediator of the relationship between obstacles and nascent entrepreneurial activity-An experimental approach. Journal of Business Venturing, 32(3), 280-301.

Krueger, N. F. (2003). The cognitive psychology of entrepreneurship. Handbook of entrepreneurship research (pp. 105-140). Springer.

Kutner, M. H., Nachtsheim, C. J., Neter, J., \& Li, W. (2005). Applied linear statistical models. McGraw-Hill.

Langowitz, N., \& Minniti, M. (2007). The entrepreneurial propensity of women. Entrepreneurship Theory and Practice, 31(3), 341-364.

Leyden, D. P., \& Link, A. N. (2015). Toward a theory of the entrepreneurial process. Small Business Economics, 44(3), 475-484.

Lieberman, M. D. (2000). Intuition: A social cognitive neuroscience approach. Psychological Bulletin, $126(1), 109-137$.

Lin, F. J. (2008). Solving multicollinearity in the process of fitting regression model using the nested estimate procedure. Quality \& Quantity, 42(3), 417-426.

Liñán, F., \& Fayolle, A. (2015). A systematic literature review on entrepreneurial intentions: Citation, thematic analyses, and research agenda. International Entrepreneurship and Management Journal, 11, 907-933.

Long, J. S., \& Freese, J. (2006). Regression models for categorical dependent variables using Stata. Stata Press.

Low, M. B., \& MacMillan, I. C. (1988). Entrepreneurship: Past research and future challenges. Journal of Management, 14(2), 139-161.

MacMillan, I. C. (1986). To really know about entrepreneurship, let's study habitual entrepreneur. Journal of Business Venturing, 1(3), 241-243.

Marvel, M. R., Davis, J. L., \& Sproul, C. R. (2016). Human capital and entrepreneurship research: A critical review and future directions. Entrepreneurship Theory and Practice, 40(3), 599-626.

Matricano, D. (2016). The impact of intellectual capital on start-up expectations. Journal of Intellectual Capital, 17(4), 654-674.

Matricano, D. (2020). The effect of R\&D investments, highly skilled employees, and patents on the performance of Italian innovative start-ups. Technology Analysis and Strategic Management, 32(10), 1195-1208.

Maula, M., Autio, E., \& Arenius, P. (2005). What drives micro-angel investments? Small Business Economics, 25(5), 459-475.

McDonald, J. F., \& Moffitt, R. A. (1980). The uses of Tobit analysis. The Review of Economics and Statistics, 62(2), 318-321. 
McGrath, R. G., \& MacMillan, I. (2000). The Entrepreneurial Mindset. Harvard Business School Press.

Meehl, P. E. (1970). Nuisance variables and the ex post facto design. In M. Radner \& S. Winokur (Eds.), Minnesota studies in philosophy of science, IV (pp. 373-402). University of Minneapolis Press.

Meehl, P. E. (1971). High school yearbooks: A reply to Schwarz. Journal of Abnormal Psychology, 77(2), 143-148.

Mill, J. S. (1848). Principles of Political Economy.

Minniti, M., \& Nardone, C. (2007). Being in someone else's shoes: The role of gender in nascent entrepreneurship. Small Business Economics, 28(2), 223-238.

Miralles, F., Giones, F., \& Riverola, C. (2016). Evaluating the impact of prior experience in entrepreneurial intention. International Entrepreneurship and Management Journal, 12, 791-813.

Mitchell, J. R., \& Shepherd, D. A. (2011). Afraid of opportunity: The effects of fear of failure on entrepreneurial action. Frontiers of Entrepreneurship Research, 31(6), 1-20.

Mitchell, J. R., Friga, P. N., \& Mitchell, R. K. (2005). Untangling the intuition mess: Intuition as a construct in entrepreneurship research. Entrepreneurship Theory and Practice, 29(6), 653-679.

Mitchell, R. K., Busenitz, L. W., Bird, B., Marie Gaglio, C., McMullen, J. S., Morse, E. A., \& Smith, J. B. (2007). The central question in entrepreneurial cognition research 2007. Entrepreneurship Theory and Practice, 31(1), 1-27.

Mitchell, R. K., Busenitz, L., Lant, T., McDougall, P. P., Morse, E. A., \& Smith, J. B. (2004). The distinctive and inclusive domain of entrepreneurial cognition research. Entrepreneurship Theory and Practice, 28(6), 505-518.

Morales-Gualdrón, S. T., \& Roig, S. (2005). The new venture decision: An analysis based on the GEM Project Database. International Entrepreneurship and Management Journal, 1, 479-499.

Mühlböck, M., Warmuth, J., Holienka, M., \& Kittel, B. (2018). Desperate entrepreneurs: No opportunities, no skills. International Entrepreneurship and Management Journal, 14, 975-997.

Nord, W., \& Fox, S. (1996). The individual in organization studies. Handbook of organization studies. Sage.

Pattinson, S. (2019). Understanding effectual decision-making in a science-based business: The case of Hart Biologicals. The International Journal of Entrepreneurship and Innovation, 20(1), 65-71.

Ramoglou, S. (2021). Knowable opportunities in an unknowable future? On the epistemological paradoxes of entrepreneurship theory. Journal of Business Venturing. https://doi.org/10.1016/j. jbusvent.2020.106090.

Ramos-Rodriguez, A., Medina-Garrido, J., Lorenzo-Gomez, J., \& Ruiz-Navarro, J. (2010). What you know or who you know? The role of intellectual and social capital in opportunity recognition. International Small Business Journal, 28(6), 566-582.

Ratner, B. (2009). The correlation coefficient: Its values range between $+1 /-1$, or do they? Journal of Targeting, Measurement and Analysis for Marketing, 17(2), 139-142.

Reynolds, P. D. (1991). Sociology and entrepreneurship: Concepts and contributions. Entrepreneurship Theory and Practice, 16(2), 47-70.

Reynolds, P. D., Bosma, N., Autio, E., Hunt, S., De Bono, N., Servais, I., Lopez-Garcia, P., \& Chin, N. (2005). Global Entrepreneurship Monitor: Data collection design and implementation 1998-2003. Small Business Economics, 24(3), 205-231.

Reynolds, P. D., Camp, S. M., Bygrave, W. D., Autio, E., \& Hay, M. (2001). Global Entrepreneurship Monitor 2001 Summary Report, Kansas City, KA: Kauffman Center for Entrepreneurial Leadership at the Ewing Marion Kauffman Foundation.

Reynolds, P. D., Storey, D. J., \& Westhead, P. (1994). Cross-national comparisons of the variation in new firm Formation Rates. Regional Studies, 28(4), 443-456.

Ripsas, S. (1998). Towards an interdisciplinary theory of entrepreneurship. Small Business Economics, 10(2), 103-115.

Robinson, A. T., \& Marino, L. D. (2015). Overconfidence and risk perceptions: Do they really matter for venture creation decisions? International Entrepreneurship and Management Journal, 11, 149-168.

Sadler-Smith, E. (2004). Cognitive style and the management of small and medium-sized enterprises. Organization Studies, 25(2), 155-181.

Sadler-Smith, E. (2016). The role of intuition in entrepreneurship and business venturing decisions. European Journal of Work and Organizational Psychology, 25(2), 212-225.

Schjoedt, L., \& Bird, B. (2014). Control variables: Use, misuse, and recommended use. In A. Carsrud \& M. E. Brännback (Eds.), Handbook of Research Methods and Applications in Entrepreneurship and Small Business (pp. 136-155). Edward Elgar. 
Schjoedt, L., Fitzsimmons, J., Datta, K. S., \& Sangboon, K. (2018). Emirati women entrepreneurs: the effects of work and family on life satisfaction. The 11th Diana International Research Conference, Bangkok, Thailand.

Schjoedt, L., \& Sangboon, K. (2015a). Room for improvement: An examination of the use of control variables. International Journal of Management and Business, 6(2), 57-73.

Schjoedt, L., \& Sangboon, K. (2015b). Control variables: Problematic issues and best practices. In K. D. Strang (Ed.), Palgrave Research Design in Business and Management (pp. 239-261). Palgrave-Macmillan.

Schumpeter, J. A. (1911). The Theory of Economic Development: An Inquiry into Profits, Capital, Credit, Interest and Business Cycle (1934th ed.). Harvard University Press.

Shaver, K. G., Schjoedt, L., Passarelli, A., \& Reeck, C. (2017). The cognitive neuroscience of entrepreneurial risk: Conceptual and methodological challenges. In M. J. Day, M. C. Boardman, \& N. Krueger (Eds.), Handbook of Research Methodologies and Design in Neuroentrepreneurship (pp. 207-240). Edward Elgar Publishing.

Shepherd, D. (2015). Party On! A call for entrepreneurship research that is more interactive, activity based, cognitively hot, compassionate, and prosocial. Journal of Business Venturing, 30(4), 489-507.

Shepherd, D. A., Douglas, E. J., \& Shanley, M. (2000). New venture survival: Ignorance, external shocks, and risk reduction strategies. Journal of Business Venturing, 15(5-6), 393-410.

Shepherd, D. A., Williams, T. A., \& Patzelt, H. (2015). Thinking about entrepreneurial decision making: Review and research agenda. Journal of Management, 41(1), 11-46.

Slotte-Kock, S., \& Coviello, N. (2010). Entrepreneurship research on network processes: A review and ways forward. Entrepreneurship Theory and Practice, 34(1), 31-57.

Spender, J. C. (1996). Making knowledge the basis of a dynamic theory of the firm. Strategic Management Journal, 17(S2), 45-62.

Spender, J. C., \& Grant, R. M. (1996). Knowledge and the firm: Overview. Strategic Management Journal, 17(S2), 5-9.

Stanovich, K. E., \& West, R. F. (2000). Individual differences in reasoning: Implications for the rationality debate? Behavioral and Brain Sciences, 23(5), 645-665.

Starr, J. A., \& MacMillan, I. C. (1990). Resource cooptation via social contracting: Resource acquisition strategies for new ventures. Strategic Management Journal, 11(1), 79-92.

Starr, J., \& Bygrave, W. (1991). The assets and liabilities of prior start-up experience: An exploratory study of multiple venture entrepreneurs. In N. Churchhill, J. Bygrave, D. Covin, D. Sexton, K. Slevin, K. Vesper, \& W. Wetzel (Eds.), Frontiers of Entrepreneurship Research. Babson College: Wellesley.

Steyaert, C. (2007). Entrepreneuring as a conceptual attractor? A review of process theories in 20 years of entrepreneurship studies. Entrepreneurship and Regional Development, 19(6), 453-477.

Sutton, F. X. (1954). Achievement Norms and the Motivation of Entrepreneurs. In Entrepreneurs and Economic Growth. Cambridge (MA): Social Science Research Council and Harvard University Research Center in Entrepreneurial History.

Timmons, J. A. (1978). Characteristics and role demands of entrepreneurship. American Journal of Small Business, 3(1), 5-17.

Troise, C., \& Tani, M. (2021). Exploring entrepreneurial characteristics, motivations and behaviours in equity crowdfunding: Some evidence from Italy. Management Decision, 59(5), 995-1024.

Ucbasaran, D., Westhead, P., Wright, M., \& Binks, M. (2003a). Does Entrepreneurial Experience Influence Opportunity Identification? The Journal of Private Equity, 7(1), 7-14.

Ucbasaran, D., Wright, M., \& Westhead, P. (2003b). A Longitudinal Study of Habitual Entrepreneurs: Starters and Acquirers. Entrepreneurship and Regional Development, 15(3), 207-228.

Unger, J. M., Rauch, A., Frese, M., \& Rosenbusch, N. (2011). Human capital and entrepreneurial success: A meta-analytical review. Journal of Business Venturing, 26(3), 341-358.

Wagner, J. (2007). What a difference a Y makes-female and male nascent entrepreneurs in Germany. Small Business Economics, 28(1), 1-21.

Welter, F. (2011). Contextualizing entrepreneurship-conceptual challenges and ways forward. Entrepreneurship Theory and Practice, 35(1), 165-184.

Welter, F., \& Gartner, W. B. (2016). A research agenda for entrepreneurship and context. Edward Elgar Publishing.

Westhead, P., \& Wright, M. (1998a). Novice, portfolio and serial founders in rural and urban areas. Entrepreneurship Theory and Practice, 22(4), 63-100. 
Westhead, P., \& Wright, M. (1998b). Novice, serial and portfolio founders: Are they different? Journal of Business Venturing, 13(3), 173-204.

Westhead, P., Ucbasaran, D., \& Wright, M. (2005). Decisions, actions and performances: Do novice, serial and portfolio entrepreneurs differ? Journal of Small Business Management, 43(4), 393-417.

Wiklund, J., \& Shepherd, D. A. (2008). Portfolio entrepreneurship: Habitual and novice founders, new entry, and mode of organizing. Entrepreneurship Theory and Practice, 32(4), 701-725.

Woo, C. Y., Daellenbach, U., \& Nicholls-nixon, C. (1994). Theory building in the presence of "randomness": The case of new venture creation and performance. Journal of Management Studies, 31(4), 507-524.

Zahra, S. A. (2007). Contextualizing theory building in entrepreneurship research. Journal of Business Venturing, 22(3), 443-452.

Zahra, S. A., Wright, M., \& Abdelgawad, S. G. (2014). Contextualization and the advancement of entrepreneurship research. International Small Business Journal, 32(5), 479-500.

Zhao, W., Yang, T., Hughes, K. D., \& Li, Y. (2020). Entrepreneurial alertness and business model innovation: The role of entrepreneurial learning and risk perception. International Entrepreneurship and Management Journal. https://doi.org/10.1007/s11365-020-00637-2

Zheng, H., Li, D., Wu, J., \& Xu, Y. (2014). The role of multidimensional social capital in crowdfunding: A comparative study in China and US. Information and Management, 51(4), 488-496.

Zivdar, M., Imanipour, N., Talebi, K., \& Hosseini, S. R. (2017). An explorative study of inputs for entrepreneurs' decision-making to create new venture in a high-tech context. The International Journal of Entrepreneurship and Innovation, 18(4), 243-255.

Publisher's Note Springer Nature remains neutral with regard to jurisdictional claims in published maps and institutional affiliations. 